\title{
THERMOREGULTORY MECHANISMS IN NEW BORN KIDS AND LAMBS
}

\author{
T. M. M. Abdel Khalek ${ }^{1}$ and H.H. Khalifa ${ }^{2}$ \\ 1- Animal Production Research Institute, Dokki, Giza, Egypt, 2- Animal Production \\ Department, Faculty of Agriculture, Al-Azhar University, Nasr City, Cairo, Egypt
}

\section{SUMMARY}

The present study was carried out at Sakha Animal Production Experimental Station belonging to Animal Production Institute. Ten lambs (3/8 Finish:5/8 Ossimi) and ten kids (3/4 Damascuss:1/4 Baladi) were selected at random from new born animals during winter season at 1, 2, 3 and 4 weeks of age. Thermoregulatory mechanisms (rectal temperature, skin temperature, ear temperature, oxygen consumption, heat production, respiration rate, tidal volume and gas volume) were measured at maximum (12:00 to 14:00) and minimum (05:00 to 07:00) ambient temperatures at each age during January - March 2002.

Meteorological data revealed that at 12:00 - 14:00 (maximum temperature), ambient temperature $\left(14.8\right.$ to $\left.22.8{ }^{\circ} \mathrm{C}\right)$ and THI (58.4 - 69.5) were within the thermoneutral zone, while at 05:00 - 07:00 (minimum temperature) the corresponding values were $9.6-15{ }^{\circ} \mathrm{C}$ and $52.5-58.6$ which lie in the cold stress range for newborn lambs and kids. Results indicated that under cold stress rectal temperature was significantly lower in kids than in lambs due to a significant reduction in rectal temperature of kids at minimum Ta during night, while no significant changes occurred in lambs. Similar trend was found in ST. The lower RT and ST of kids at minimum Ta than at maximum Ta, while no significant changes occurred in lambs indicates that kids are less cold tolerance than lambs. In both breeds, the occurrence of vasoconstriction was observed from the significant decrease in ear temperature at night in both kids and lambs. In kids, gas volume $(G V)$ tended to increase due to a significant increase in tidal volume (TV) while respiration rate $(R R)$ increased insignificantly at night revealing more heat loss by evaporative cooling in kids than in lambs under cold stress at night. Heat production (HP) was significantly lower in kids than in lambs during at maximum and minimum temperatures although the reduction in heat production in lambs at night.

It could be concluded that the main cause of higher mortality rate in new born kids than lambs is due to lower metabolic rate and higher heat loss in kids than in lambs so that kids cannot tolerate the effect of cold stress at night in winter.

Keywords: New born, Lambs, Kids, Thermoregulation, Metabolic rate

\section{INTRODUCTION}

High mortality rate in newborn lambs and kids is one of the most important problems during cold weather in Egypt. This problem is not a simple one, as it is not

Issued by The Egyptian Society of Animal Production 
related to a specific cause but is due to multifactor attributed to climatic conditions, environmental inadequacies and other factors.

Under cold environment, a mammal can defend itself against hypothermia by conserving its body heat through increasing total body insulation and/or by increasing its heat production. Few species abandon strict homoeothermic and favor a more economic mechanism from an energy expenditure viewpoint to enhance their survival, i.e. hibernation (Khalifa, 2003).

In Egypt, Finn sheep has been used in intensive crossbreeding program to increase lamb production of indigenous breeds of sheep. Utilization of Damascus goat as a more developed breed native to the Middle East was considered as a possible mean for developing the productive potentiality of Baladi goats.

Eales, et al. (1982) defined two periods of high risk for neonatal hypothermia: birth to $5 \mathrm{~h}$ of age and 12 to $36 \mathrm{~h}$ of age. In the first period, the major cause of hypothermia was excessive heat loss. However, in the older lambs hypothermia largely resulted from decline in heat production associated with a depletion of energy reserves. A viable lamb must, therefore, be vigorously homeothermic at birth and possess sufficient energy reserves. Brown adipose tissue (BTa) is known to be the primary site of non shivering heat production in the newborn mammal (Dawkins and Hull, 1964; Hull, 1965 and Hull and Segall, 1965). White adipose tissue (WTa) is specialized for energy storage and brown adipose tissue (BTa) for heat production. The BTa function is important for thermoregulation in neonates and is implicated in diet-induced thermogenesis (Himms-Hagen, 1990).

The objective of this study is to investigate the thermoregulatory mechanisms and some physiological responses of newborn Ossimi X Finn crossbred sheep (lambs) and Damascus X Baladi crossbred goat (kids) to cold stress during winter season under Egyptian conditions in an attempt to spot light on cold tolerance and its relation to high mortality rate in lambs and kids.

\section{MATERIALS AND METHODS}

This study was carried out on 20 new born lambs and kids, 10 cross-breed 3/8 Finnish Landrase X 5/8 Ossimi lambs and 10 cross-breed 3/4 Damascus X 1/4 Baladi kids. The new born animals as well as their dams were maintained in one pen from birth until weaning and were allowed to suckle their Dams naturally 3 hours before the experimental work. All animals were returned to their dams at the end of the experimental trials. During suckling periods, dams and their offspring's were housed loose in semi-open shaded yard. During cold season dams were fed ad lib. on Egyptian clover (Trifolium alexandrinum) in addition to concentrate mixture (500 $\mathrm{g} / \mathrm{head} /$ day). The concentrate mixture contained of $12 \%$ crude protein and $50 \%$ starch value and consisted of $35 \%$ decorticated cotton seed meal, $22 \%$ corn, $33 \%$ wheat bran, $4 \%$ rice bran, $3 \%$ molasses, $2 \%$ lime stone and $1 \%$ salt. Fresh tap water was available ad lib. during the day for drinking.

The experiment was carried out during the coldest months of winter season (January - March 2002). Ambient temperature (Ta) and relative humidity (RH\%) were recorded simultaneously while measuring the physiological responses using the 
method described by Hertig (1968). The Temperature-Humidity Index (THI) was calculated from Ta and RH according to Hahn et al. (2003):

THI $=\left(\left(\mathrm{TDB}^{*} 1.8\right)+32\right)-((0.55 *(\mathrm{RH} / 100))) *\left(\left(\left(\mathrm{TDB}^{*} 1.8\right)+32\right)-58\right)$.

Where:

TDB $=$ Dry bulb temperature in ${ }^{\circ} \mathrm{C}$.

$\mathrm{RH}=$ Relative humidity in $\%$

The physiological parameters were taken twice daily, at maximum Ta from 12.00 to 14.00 and at minimum $\mathrm{Ta}$ at night from 05.00 to 07.00 . Rectal temperature (RT, ${ }^{\circ} \mathrm{C}$ ) was measured using a clinical thermometer. Skin temperature $\left(\mathrm{ST},{ }^{\circ} \mathrm{C}\right)$, ear temperature $\left(\mathrm{ET},{ }^{\circ} \mathrm{C}\right)$ and coat surface temperature $\left(\mathrm{CST},{ }^{\circ} \mathrm{C}\right)$ were measured using the Minolta/Land Cyclops Compac 3 portable infrared thermometer. Respiration rate (RR) was measured by counting the flank movements in one minute. Respiratory minute volume as 1/minute (GV) was measured by Dry Gas Meter. Tidal volume was calculated by dividing GV/RR. Heat production (HP), measured as fasting metabolic rate, $\mathrm{kcal} / \mathrm{BW}^{0.75}$ per day, was calculated using the equation of Brouwer (1965). The measurement of oxygen consumption $\left(\mathrm{VO}_{2}\right)$ and carbon dioxide production $\left(\mathrm{VCO}_{2}\right)$ were made using the open-circuit technique according to Yousef and Dill (1969). Oxygen consumption was calculated from the oxygen deficit in expired air using oxygen analyzer (Servomex 570). The rate of carbon dioxide production was calculated from the $\mathrm{CO}_{2}$ increase in expired air obtained from infrared Gas Analyzer (Model-AR-411).

The statistical analysis of data was carried out using SAS program (SAS, 1990). Student $t$ test (Proc TTest of SAS) was used to test the significance for the effect of breed (between kids and lambs) within each age and diurnal interval as well as the effect of diurnal variation within each age and breed. Analysis of variance (Proc GLM of SAS) followed by Duncan's Multiple Range Test were used to test the effect of age within each breed and diurnal interval.

\section{RESULTS AND DISCUSSION}

Meteorological data (Table 1) revealed that at 12:00 - 14:00 (maximum temperature), ambient temperature and THI (14.8 to $22.8{ }^{\circ} \mathrm{C}$ and $58.4-69.5$, respectively) were within the thermoneutral zone, while at 05:00 - 07:00 (minimum temperature) they were within the cold stress range $\left(9.6-15{ }^{\circ} \mathrm{C}\right.$ and $52.5-58.6$ for ambient temperature and THI, respectively) for neonatal lambs and kids. ElSherbiny et al. (1983) reported that the lower critical temperature of adult Egyptian Arabi and Zaraiby goats ranged between $10-15^{\circ} \mathrm{C}$.

During the first week of age rectal temperature (RT) of kids was significantly lower than lambs at the maximum $\mathrm{Ta}$, while the difference was insignificant at the minimum Ta. This was due to an insignificant increase in RT of kids during minimum Ta meanwhile RT of lambs was almost unchanged. At maximum Ta, RT of kids tended to increase with age, while it tended to decrease at minimum Ta being significant at 3 and 4 weeks of age. In sheep, age and diurnal variation had no 
significant effect on RT. Consequently, at 2, 3 and 4 weeks of age RT at minimum Ta was significantly lower in kids than in lambs. These results indicate that until 4 weeks of age, when Ta was lower than $15^{\circ} \mathrm{C}\left(9.6-11.3^{\circ} \mathrm{C}\right)$ kids could not maintain their body temperature and a significant decrease in RT occurred, while lambs can tolerate such temperatures as indicated by the insignificant changes in their RT (ranged between $39.8-39.9^{\circ} \mathrm{C}$ ). Srikandakumar et al. (2003) concluded that Omani sheep were more adapted than Merino because the basal rectal temperature was higher in Merino $\left(39.5^{\circ} \mathrm{C}\right)$ than Omani $\left(39^{\circ} \mathrm{C}\right)$ sheep during the period of cold environment. However, the higher RT in lambs than in kids at minimum $\mathrm{Ta}$ in the present study cannot be explained as kids are more cold tolerant than lambs because it was coincided with higher RR and metabolic rate in lambs than in kids indicating that the lower RT in kids was due to inability to enhance metabolic rate during cold stress.

Table 1. Meteorological data during the experimental period (January-March, 2002)

\begin{tabular}{ccccccc}
\hline \multirow{2}{*}{$\begin{array}{c}\text { Age } \\
\text { (week) }\end{array}$} & \multicolumn{2}{c}{ Ta $\left({ }^{\circ} \mathbf{C}\right)$} & \multicolumn{2}{c}{ RH\% } & \multicolumn{2}{c}{ THI } \\
\hline 1 & 15 & 19.8 & 76.5 & 58.7 & 58.6 & 64.5 \\
2 & 10 & 17.2 & 68.0 & 53.8 & 53.0 & 61.5 \\
3 & 9.6 & 14.8 & 67.3 & 67.0 & 52.5 & 58.4 \\
4 & 11.3 & 22.8 & 67.0 & 43.0 & 54.4 & 69.5 \\
\hline
\end{tabular}

Min. = Minimum (05:00-07:00)

Max. = Maximum (12:00-14:00)

The significantly lower RT of kids at minimum Ta after 3 weeks of age than at the first week of age was due to the decrease in Ta and THI compared with the first week of age (Tables, $2 \& 3$ ). This result indicates that until the $4^{\text {th }}$ week of age kids cannot tolerate the decrease in Ta below $15{ }^{\circ} \mathrm{C}(\mathrm{THI}<58)$. Lowe et al. (2002) reported that respiration rate $(\mathrm{RR})$ and rectal temperature $(\mathrm{RT})$ were highly correlated with increasing temperature humidity index (THI) $(r>0.75, P<0.001)$, whereas heart rate was less responsive to THI $(r=0.30, P<0.05)$.

The mean rectal temperature in the present study was within the range $(38.3-$ $41^{\circ} \mathrm{C}$ ) which has been reported on sheep by many authors (Symington, 1960; Terill, 1968; Swenson and Reece, 1993, Shafie et al., 1994 and Shalaby et al., 1996). Meanwhile, RT of kids was higher than that reported by Ghosh et al. (1993) and Kumar and Singh (1994) who stated that the overall average rectal temperature of goats was $38.53 \pm 0.06^{\circ} \mathrm{C}$ and $38.59 \pm 0.04^{\circ} \mathrm{C}$, respectively. Ghosh et al. (1993) added that the overall average rectal temperature of goats was significantly positively related to Ta. However, the present results were in accordance with Ibrahim (2000). Faurie et al. (2004) reported that immediately after birth in the field, the core temperature of newborn lambs fell by up to $4.5{ }^{\circ} \mathrm{C}$. Thereafter, newborn lambs increased their core body temperatures and appeared to regulate core temperature and daily temperature rhythms at the same levels that they 
were as fetuses. Only in the second month post-partum, lamb core temperatures and temperature rhythms begin to resemble those of adult sheep.

Table 2. Effect of age, breed and diurnal variation on rectal temperature (RT, $\left.{ }^{\circ} \mathrm{C}\right)$, skin temperature $\left(\mathrm{ST},{ }^{\circ} \mathrm{C}\right)$, ear temperature $\left(\mathrm{ET},{ }^{\circ} \mathrm{C}\right)$ and coat surface temperature (CST, ${ }^{\circ} \mathrm{C}$ ) of new born kids and lambs during winter

\begin{tabular}{|c|c|c|c|c|c|c|c|}
\hline & \multirow{2}{*}{$\begin{array}{c}\text { Age } \\
\text { (week) }\end{array}$} & \multicolumn{2}{|c|}{ Maximum temperature } & \multicolumn{2}{|c|}{ Minimum temperature } & \multicolumn{2}{|c|}{ Kids Lambs } \\
\hline & & Kids & Lambs & Kids & Lambs & P1 P2 & $\mathrm{P} 2$ \\
\hline \multirow[t]{4}{*}{$\mathrm{RT}^{\circ} \mathrm{C}$} & 1 & $39.3 \pm 0.10^{b}$ & $39.8 \pm 0.09^{\mathrm{a}}$ & $* * 39.5 \pm 0.14^{\mathrm{a}}$ & $39.8 \pm 0.12^{\mathrm{a}}$ & NS NS & NS \\
\hline & 2 & $39.5 \pm 0.10^{\mathrm{a}}$ & $39.7 \pm 0.50^{\mathrm{a}}$ & NS $39.3 \pm 0.08^{a b}$ & $39.9 \pm 0.07^{\mathrm{a}}$ & $* * \mathrm{NS}$ & NS \\
\hline & 3 & $39.7 \pm 0.11^{\mathrm{a}}$ & $39.8 \pm 0.07^{\mathrm{a}}$ & NS $39.2 \pm 0.12^{b}$ & $39.8 \pm 0.11^{\mathrm{a}}$ & $* * \quad * *$ & NS \\
\hline & 4 & $39.7 \pm 0.06^{\mathrm{a}}$ & $39.8 \pm 0.06^{\mathrm{a}}$ & NS $39.2 \pm 0.09^{\mathrm{ab}}$ & $39.9 \pm 0.06^{\mathrm{a}}$ & $* * \quad * *$ & NS \\
\hline \multirow[t]{4}{*}{$\mathrm{ST}^{\circ} \mathrm{C}$} & 1 & $36.7 \pm 0.30^{\mathrm{a}}$ & $35.2 \pm 0.47^{\mathrm{ab}}$ & $* * 36.6 \pm 0.27^{\mathrm{a}}$ & $34.8 \pm 0.64^{\mathrm{a}}$ & $* * \mathrm{NS}$ & NS \\
\hline & 2 & $36.6 \pm 0.24^{\mathrm{a}}$ & $34.9 \pm 0.61^{\mathrm{b}}$ & $* * 35.3 \pm 0.27^{\mathrm{b}}$ & $34.8 \pm 0.35^{\mathrm{a}}$ & $\mathrm{NS} * *$ & NS \\
\hline & 3 & $35.3 \pm 0.48^{b}$ & $36.6 \pm 0.40^{\mathrm{a}}$ & $* 35.8 \pm 0.14^{\mathrm{ab}}$ & $35.8 \pm 0.46^{\mathrm{a}}$ & NS NS & NS \\
\hline & 4 & $37.2 \pm 0.19^{\mathrm{a}}$ & $36.3 \pm 0.41^{\mathrm{a}}$ & * $35.2 \pm 0.46^{\mathrm{b}}$ & $35.5 \pm 0.47^{\mathrm{a}}$ & $\mathrm{NS} * *$ & NS \\
\hline \multirow[t]{4}{*}{$\mathrm{ET}^{\circ} \mathrm{C}$} & 1 & $30.5 \pm 0.95^{b}$ & $29.9 \pm 0.72^{\mathrm{a}}$ & NS $27.5 \pm 0.99^{a}$ & $29.4 \pm 1.90^{\mathrm{a}}$ & NS & NS \\
\hline & 2 & $26.1 \pm 1.11^{\mathrm{c}}$ & $29.3 \pm 1.08^{\mathrm{a}}$ & * $23.9 \pm 0.82^{\mathrm{b}}$ & $23.9 \pm 0.90^{b}$ & NS NS & $* *$ \\
\hline & 3 & $28.5 \pm 1.41^{\mathrm{bc}}$ & $30.2 \pm 1.10^{\mathrm{a}}$ & NS $24.0 \pm 0.92^{b}$ & $25.6 \pm 1.20^{\mathrm{ab}}$ & NS $* *$ & $* *$ \\
\hline & 4 & $33.9 \pm 0.88^{\mathrm{a}}$ & $32.1 \pm 1.03^{\mathrm{a}}$ & NS $26.2 \pm 1.20^{\mathrm{ab}}$ & $24.3 \pm 0.95^{b}$ & NS $* *$ & $* *$ \\
\hline \multirow[t]{4}{*}{$\mathrm{CST}^{\circ} \mathrm{C}$} & 1 & $30.5 \pm 0.51^{\mathrm{a}}$ & $29.4 \pm 0.49^{\mathrm{a}}$ & NS $29.5 \pm 0.35^{\mathrm{a}}$ & $29.1 \pm 0.68^{\mathrm{a}}$ & NS NS & NS \\
\hline & 2 & $29.8 \pm 0.51^{\mathrm{a}}$ & $27.9 \pm 0.51^{\mathrm{ab}}$ & $* * 27.0 \pm 0.24^{b}$ & $27.6 \pm 0.38^{\mathrm{ab}}$ & $\mathrm{NS} * *$ & NS \\
\hline & 3 & $27.6 \pm 0.51^{b}$ & $28.9 \pm 0.36^{\mathrm{ab}}$ & $* 26.7 \pm 0.24^{b}$ & $25.8 \pm 0.66^{\mathrm{b}}$ & NS NS & $* *$ \\
\hline & 4 & $31.1 \pm 0.41^{\mathrm{a}}$ & $27.4 \pm 0.73^{b}$ & $* * 27.3 \pm 0.49^{b}$ & $25.8 \pm 0.85^{b}$ & NS $* *$ & NS \\
\hline
\end{tabular}

$\mathrm{a}, \mathrm{b}, \mathrm{c}$ similar letters within each column and variable are not significant $(\mathrm{p} \leq 0.05)$

$\mathrm{P} 1=$ Probability level for the effect of breed.

P2 = Probability level for the effect of diurnal variation.

$\mathrm{NS}=$ Insignificant $(\mathrm{p}>0.05)$.

* = Significant at $\mathrm{p} \leq 0.05$

$* *$ Significant at $\mathrm{p} \leq 0.01$

Ibrahim (2000) stated that RT of $1 / 2$ Finnish Landrace $x$ Rahmani (1/2 FR) and 3/8 FR lambs and 3/4 Damascus X 1/4 Baladi kids were higher in the afternoon in winter $\left(40.1{ }^{\circ} \mathrm{C}\right)$ than at the morning $\left(39.8{ }^{\circ} \mathrm{C}\right)$. A similar trend was noticed at 2 weeks of age when RT of lambs was slightly higher at 05:00 - 07:00 than at $12: 00-14: 00$ (39.7 vs. $39.9{ }^{\circ} \mathrm{C}$, respectively). Piccione et al. (2002) demonstrated that the diurnal variation in RT of sheep of $1{ }^{\circ} \mathrm{C}$ between dawn and dusk was fully attained a month after birth. However, no significant diurnal variation in RT of lambs was found until 4 weeks of age. Ayo et al. (1998) reported that RT of the Red Sokoto goat rose significantly $(P<0.001)$ from the minimum value of $38.30 \pm 0.8{ }^{\circ} \mathrm{C}$ at $06.00 \mathrm{~h}$ to the maximum value of $39.40 \pm 0.04$ ${ }^{\circ} \mathrm{C}$ at $18.00 \mathrm{~h}$. 
Table 3. Effect of age, breed and diurnal variation on respiration rat (RR/r.p.m), gas volume (GV l/min), tidal volume (TV $\mathrm{ml} / \mathrm{min}$.) and heat production (HP kcal/BW ${ }^{0.75}$ per day) of new born animals during winter

\begin{tabular}{|c|c|c|c|c|c|c|c|}
\hline \multirow[b]{2}{*}{$\begin{array}{l}\text { Age } \\
\text { (week) }\end{array}$} & \multicolumn{2}{|c|}{ Maximum temperature } & \multicolumn{3}{|c|}{ Minimum temperature } & \multicolumn{2}{|c|}{ Kids Lambs } \\
\hline & Kids & Lambs & P1 & Kids & Lambs & P1 P2 & $\mathrm{P} 2$ \\
\hline RR 1 & $66.7 \pm 8.4^{\mathrm{a}}$ & $69.8 \pm 3.6^{\mathrm{a}}$ & NS & $66.3 \pm 5.2^{\mathrm{a}}$ & $69.4 \pm 2.9^{\mathrm{a}}$ & NS NS & NS \\
\hline 2 & $45.8 \pm 2.8^{b}$ & $62.3 \pm 2.5^{\mathrm{a}}$ & $* *$ & $42.4 \pm 4.0^{\mathrm{b}}$ & $63.1 \pm 4.3^{\mathrm{ab}}$ & $* * \mathrm{NS}$ & NS \\
\hline 3 & $41.5 \pm 4.9^{b}$ & $52.9 \pm 3.3^{b}$ & NS & $34.6 \pm 3.5^{b}$ & $53.8 \pm 3.1^{b c}$ & $* * \mathrm{NS}$ & NS \\
\hline 4 & $41.8 \pm 2.6^{b}$ & $51.8 \pm 2.6^{\mathrm{b}}$ & & $32.1 \pm 2.5^{b}$ & $49.4 \pm 3.3^{c}$ & $* * *$ & NS \\
\hline GV 1 & $2.09 \pm .13^{\mathrm{a}}$ & $4.39 \pm .24^{c}$ & $* *$ & $1.99 \pm .15^{\mathrm{a}}$ & $5.10 \pm .22^{\mathrm{c}}$ & $* * \mathrm{NS}$ & NS \\
\hline 2 & $1.90 \pm .11^{\mathrm{a}}$ & $3.72 \pm .19^{c}$ & $* *$ & $2.07 \pm .16^{\mathrm{a}}$ & $3.93 \pm .15^{\mathrm{d}}$ & $* * \mathrm{NS}$ & NS \\
\hline 3 & $1.98 \pm .09^{\mathrm{a}}$ & $6.79 \pm .36^{\mathrm{b}}$ & $* *$ & $2.01 \pm .09^{\mathrm{a}}$ & $7.65 \pm .41^{\mathrm{b}}$ & ** NS & NS \\
\hline 4 & $1.97 \pm .11^{\mathrm{a}}$ & $8.21 \pm .42^{\mathrm{a}}$ & $* *$ & $2.02 \pm .10^{\mathrm{a}}$ & $9.27 \pm .43^{\mathrm{a}}$ & $* * \mathrm{NS}$ & NS \\
\hline TV 1 & $34.5 \pm 3.54^{b}$ & $49.5 \pm 3.65^{\mathrm{ab}}$ & $* *$ & $31.5 \pm 3.15^{b}$ & $33.3 \pm 3.08^{c}$ & NS NS & $* *$ \\
\hline 2 & $43.4 \pm 3.98^{\mathrm{b}}$ & $43.8 \pm 2.60^{\mathrm{b}}$ & & $52.0 \pm 4.82^{\mathrm{a}}$ & $53.8 \pm 3.51^{\mathrm{b}}$ & NS NS & $*$ \\
\hline 3 & $52.6 \pm 4.52^{\mathrm{a}}$ & $55.8 \pm 2.76^{\mathrm{a}}$ & & $63.2 \pm 5.16^{\mathrm{a}}$ & $62.6 \pm 5.85^{\mathrm{ab}}$ & NS NS & NS \\
\hline 4 & $48.2 \pm 2.58^{\mathrm{a}}$ & $54.04 \pm 3.74^{\mathrm{a}}$ & & $67.8 \pm 6.74^{\mathrm{a}}$ & $76.7 \pm 7.22^{\mathrm{a}}$ & NS * & $*$ \\
\hline HP 1 & $72.0 \pm 9.6^{\mathrm{a}}$ & $154.6 \pm 9.80^{b}$ & $* *$ & $86.4 \pm 10.3^{\mathrm{a}}$ & $114.7 \pm 10.3^{c}$ & NS NS & $*$ \\
\hline 2 & $73.9 \pm 8.2^{\mathrm{a}}$ & $112.1 \pm 11.3^{c}$ & $*$ & $61.9 \pm 08.2^{b}$ & $117.1 \pm 07.2^{\mathrm{c}}$ & $* * \mathrm{NS}$ & NS \\
\hline 3 & $84.0 \pm 5.5^{\mathrm{a}}$ & $197.3 \pm 9.60^{\mathrm{a}}$ & $* *$ & $84.0 \pm 05.5^{\mathrm{ab}}$ & $207.1 \pm 10.1^{b}$ & $* * \mathrm{NS}$ & NS \\
\hline 4 & $72.0 \pm 7.2^{\mathrm{a}}$ & $223.9 \pm 12.3^{\mathrm{a}}$ & $* *$ & $72.0 \pm 06.7^{\mathrm{ab}}$ & $264.0 \pm 10.1^{\mathrm{a}}$ & $* * \mathrm{NS}$ & $*$ \\
\hline
\end{tabular}

$a, b, c$ similar letters within each column and variable are not significant $(\mathrm{p} \leq 0.05)$

p1 = Probability level for the effect of breed.

$\mathrm{P} 2$ = Probability level for the effect of diurnal variation.

$\mathrm{NS}=$ Insignificant $(\mathrm{p}>0.05)$.

$* \quad=$ Significant at $\mathrm{p} \leq 0.05$

$* *=$ Significant at $\mathrm{p} \leq 0.01$

In lambs, ST tended to increase with age. It was higher at 3 and 4 weeks of age than at 2 weeks of age but the difference was significant only at maximum TA. The effect of age on ST of kids was conflicting indicating that changes in ST in kids depend more on Ta than on age. This conclusion is confirmed by the significantly lower ST of kids at minimum than at maximum Ta (at 2 and 4 weeks of age). As a result, at maximum Ta, ST was significantly higher in kids than in lambs at all ages except at 3 weeks of age where lambs had higher ST than kids. At minimum Ta, ST was higher in kids than in lambs at 1 (significant) and 2 (insignificant) weeks of age, while it was almost similar in both breeds at 3 and 4 weeks of age. Similar results were reported by Ibrahim (2000) who stated that the ST of kids showed higher values than lambs in the morning or afternoon and the difference between the two species was highly significant. Shalaby and Johnson (1993) found that the overall mean of skin temperature of goats was $32.9{ }^{\circ} \mathrm{C}$ which is lower than the present 
values. They added that skin temperature of Anglo-Nubian goats increased significantly with Ta. Khalifa et al. (1997) found that ST of kids was significantly higher in summer than in winter.

Ear temperature did not differ significantly between kids and lambs at any age except at 2 weeks of age at maximum Ta where it was significantly lower in kids than in lambs. Table (2) shows that diurnal variations extended the most pronounced effect on ET, where ET of both kids and lambs decreased significantly with the depression in Ta at dawn regardless of age. Abd El-Bary (1990) found that the ET of lambs was significantly higher during day than during night. This variation in ET between day and night attributed to variation in Ta, $\mathrm{RH} \%$ and wind velocity. In goats, Khalifa et al. (1997) found that ET of kids was significantly higher in summer than in winter. El-Sherbiny et al. (1983) found that increasing air temperature from 10 to $40^{\circ} \mathrm{C}$ increased significantly ear temperature of Egyptian Arabi and Zaraiby goats. Ear temperature exceeded skin temperature when air temperature was higher than $20^{\circ} \mathrm{C}$ by an amount of $1.5^{\circ} \mathrm{C}$. They suggested that the increase in ET reflected the occurrence of vasodilatation and opening of arteriovenous anastomosis in ears.

Coat surface temperature had similar trends to those of ST. It was significantly higher in kids than in lambs during maximum Ta except at the $1^{\text {st }}$ week of age and tended to decrease with Ta at minimum Ta. Ibrahim (2000) found that the coat surface temperature $\left(\mathrm{CST},{ }^{\circ} \mathrm{C}\right)$ of kids was significantly higher than that of lambs in the morning and afternoon by 0.9 and $2.2{ }^{\circ} \mathrm{C}$, respectively. Similar results were found in the present result at maximum $\mathrm{Ta}$ in winter while no significant changes were observed at minimum Ta.

The above results indicate that kids cannot tolerate the effect of cold stress during night in winter ( Ta below $15^{\circ} \mathrm{C}$ and $\mathrm{THI}<58$ ) as indicated by the lower RT and ST of kids at minimum Ta than at maximum Ta, while no significant changes occurred in lambs. In both breeds, the occurrence of vasoconstriction was observed from the significant decrease in ear temperature at night in both kids and lambs. As a result, lambs are more cold tolerant than kids may be due to their better thermo-isolation qualities of their fleece. Doubek et al. (2003) explained that the weaker thyroidal response of lambs of Romney Marsh breed as compared to the Merino ones under cold stress could be associated with a higher level of physical thermoregulation (better thermo-isolation qualities of their fleece).

Table (3) reveals that there were no significant changes in gas volume with age in kids, while a significant increase in gas volume occurred with age in lambs. This significant increase in GV in lambs with age was due to the significant increase in their TV although RR decreased significantly with age. On the other hand in kids GV did not differ significantly with age because the significant increase in TV compensated the significant reduction in RR with age. These results indicate that the insignificant changes in GV in kids with age was due to more pronounced significant reduction in RR with age in kids than in lambs, meanwhile the significant increase in TV was more pronounced in lambs than in kids. Kaushish et al. (2000) found that the RR and RT of lambs were higher at birth and then gradually decreased reaching adult values by 6 months of age. 
Table (3) shows also that at all ages, gas volume was significantly higher in lambs than in kids. At maximum Ta (12:00 to 14:00), the significantly higher GV in lambs than in kids at all ages was due to their higher RR and TV. However during minimum Ta (05:00 to 07:00), the significantly higher GV in lambs than in kids was mainly due to significantly higher RR except at one week of age where it was due to their higher TV. It is worthnoting that the preset values of RR, GV and TV were within the values reported in sheep (Abd-El-Bary, 1990) and kids (Ibrahim, 2000).

Although there was no significant diurnal variation (maximum vs. minimum Ta) in gas volume of both lambs and kids it tended to increase at minimum Ta (Table, 3). This slight increase in GV at minimum Ta was due to the increase in TV to enhance gas exchange in an attempt to increase in oxygen consumption although RR decreased significantly especially in kids to minimize evaporative heat loss. ElSherbiny et al. (1983) reported that the TV of goats increased significantly at colder Ta $\left(10-15^{\circ} \mathrm{C}\right)$ and decreased at higher Ta $\left(35-40^{\circ} \mathrm{C}\right)$. Abd-El-Bary (1982) suggested that the higher TV in winter than in summer may be due to the higher demand of oxygen consumption in winter than in summer. Butswat et al. (2000) stated that an increase in respiration rate appeared to be the immediate response of sheep to environmental stress.

The above results indicate that under cold environment, neonatal kids had significantly lower respiratory evaporative heat loss (GV and RR) than lambs, while TV was almost similar in both breeds especially at minimum Ta. Lowe et al. (2002) stated that respiration rate (RR) and rectal temperature (RT) were highly correlated with increasing temperature humidity index (THI) $(r>0.75, P<0.001)$,

In lambs, heat production at maximum and minimum Ta increased significantly with age. The significant lower HP under minimum Ta at 1 week age disappeared with the advance in age and reversed at 3 and 4 weeks of age to be higher at minimum Ta than at maximum one. These significant changes in HP with age and diurnal variations were not found in kids. As a result, HP at maximum and minimum Ta was significantly lower in kids than in lambs at all ages except at 1 week of age at minimum Ta where the effect was insignificant. Kid's HP in the present study was within the range found by Ibrahim (2000). He showed that in winter the daily values of kids HP did not differ significantly $(89.6 \pm 2.4$ and $80.1 \pm 2.5$ at morning and afternoon, respectively). Christensen et al. (1990) revealed that chronic cold exposure increased $(\mathrm{P}<0.05) \mathrm{Hp}$ by $41.4 \%$ of that of the thermoneutral environment. On the other hand, Freetly et al. (2002) stated that HP per unit BW decreased as sheep aged which is opposite to the present results. This may be explained on the basis that the study of Freetly et al. (2002) was carried out on ewe lambs aged 114 days.

\section{GENERAL DISCUSSION}

Under cold environment kids cannot maintain their body temperature (RT), although they reduce their respiratory evaporative heat loss (RR and GV), due to the significantly lower HP compared with lambs. This lower HP in kids was not due to the decrease in gas exchange or lung capacity because their TV was almost similar to that of lambs. As a result, the lower HP in kids than in lambs 
under cold stress may be due to lower brown adipose tissue in kids than in lambs (unpublished data) or to the lake of shivering thermogenesis and thermoinsulation quality of coat in kids. Moreover, a weaker thyroid response of kids compared to lambs may explain their cold intolerance. Doubek et al. (2003) the weaker thyroidal response of lambs of Romney Marsh breed as compared to the Merino ones could be associated with a higher level of physical thermoregulation (i.e. better thermo-isolation qualities of their fleece). They added that the activation of the thyrotropic axis together with shivering thermogenesis resulted in a significant increase in the rectal temperature in lambs of both breeds immediately after the potentiation of cold stress. Smith et al. (2004) found that brown adipose tissue from neonatal lambs was depleted of lipid in response to cold exposure. The lower RT and RR in kids than in lambs at minimum Ta gave a false interpretation that kids are more cold tolerant than lambs as concluded from results of Kaushish et al. (2000) who stated that RR and RT were higher in crossbreds than in native lambs. However, the lower HP in kids than in lambs indicated that kids are less cold tolerant than lambs because they failed to raise their HP to maintain their RT. This result confirm the conclusion of Starling et al. (2002) who stated that the use of physiological parameters such as RT and RR for selection is not enough to evaluate the level of adaptation.

The lower critical temperature of kids is higher than $15^{\circ} \mathrm{C}$ as indicated by the decrease in RT and HP of kids under this level of Ta. Meanwhile, lambs can maintain their RT under this level of Ta. The inability of kids to maintain their body temperature below $15^{\circ} \mathrm{C}$ was due mainly to the low HP although they decreased their evaporative heat loss. The lower HP in kids than in lambs under cold stress may be due to lower content of brown adipose tissue in kids than in lambs and/or to the lake of shivering thermogenesis and thermo-insulation quality of coat in kids compared with lambs.

\section{REFERENCES}

Abd-El-Bary, H.T., 1982. Energetic cost of sheep under Egyptian conditions. Ph.D. Thesis, Fac. Agric., Al-Azhar Univ., Cairo, Egypt.

Abd-El-Bary, H.T., 1990. Blood plasma protein levels during different physiological stages of fat-tailed ewes. Al-Azhar J. Agric. Res., 12: 113.

Ayo, J.O., S.B., Oladele, A., Fayomi, S.D., Jumbo and J.O., Hambolu., 1998. Body temperature, respiration and heart rate in the Red Sokoto goat during the harmattan season. Bulletin of Animal Health and Production in Africa, 46(3): 161.

Brouwer, E., 1965. In energy metabolism (ed.) K.L. Blaxter, pp. 441-443. Proceedings of $3^{\text {rd }}$ Symposium of Energy Metabolism. London, Academic Press.

Butswat, I. S. , S. T. Mbap; G. A. Ayibatonye, 2000. Heat tolerance of sheep in Bauchi, Nigeria. Tropical Agriculture , 2000 , 77 , 4 , 265.

Christensen, R.A., R.J Christopherson,. and J.J. Kennelly, 1990. Effect of somatostatin and chronic cold exposure on hormonal and metabolic concentration, metabolic rate, thermoregulation, and gut motility in sheep. Can. J. Anim. Sci., 70: 1073. 
Dawkins, M.J.R. and D. Hull, 1964. Brown adipose tissue and the response of newborn rabbits to cold. J.Physiol.172:216.

Doubek, J., S. Slosárková, P. Fleischer, G. Malá, M. Skrivánek, 2003. Metabolic and hormonal profiles of potentiated cold stress in lambs during early postnatal period. Czech Journal of Animal Science , 48 , 10 , 403.

Eales, F. A., J.S Gilmour, R.M Barlow, and J. Small, 1982.Causes of hypothermia in 89 lambs. Vet.Rec.110:118.

El-Sherbiny, A.A. M.K Yousef, M.H Salem, H.H. Khalifa, H.T. Abd El-Bary, and M.H. Khalil, 1983. Thermoregulatory responses of a desert and non-desert goat breed. Al-Azhar J. Agric. Res. Bull., 89.

Faurie, A. S., D. Mitchell, H. P. Laburn, 2004. Peripartum body temperatures in free-ranging ewes (Ovis aries) and their lambs. Journal of Thermal Biology , 29 , 2,115 .

Freetly, H. C., J. A. Nienaber, T. Brown-Brandl, 2002. Relationships among heat production, body weight, and age in Finnsheep and Rambouillet ewes.

Journal of Animal Science , 2002, 80 , 3 , 825.

Ghosh, N., A.K. Samanta, S.P.Roy, and D.N. Maitra, 1993. Studies on the physiology responses and feed intake of Bengal goats under deep litter system of management. Indian J. Anim. Prod. and Manag., 9: 161.

Hahn, G.L., T.L. Mader, and R.A. Eigenberg, 2003. Perspective on development of thermal indices for animal studies and management. Proceeding of the Interaction Between Climate and Animal Production Symposium, Viterbo, Italy, September, 2003, EAAP Technical Series No. 7: 31-44.

Hertig, B.A., 1968.Measurement of the physical environment. Chapter 23 In: Adaptation of Domestic Animals, Hafez, S.E.(ed.).Lea and Febiger, Philadelphia, USA, pp. 325.

Himms-Hagen, J., 1990. Brown adipose tissue thermogenesis : Interdiciplinary studies FASEB J. 11:2890.

Hull, D., 1965. Oxygen consumption and body temperature of newborn rabbits and kittens exposed to cold. J.Physiol.177:192.

Hull, D. and M.M. Segall ,1965.The contribution of brown adipose tissue to heat production in the newborn rabbit . J.Physiol.181:449.

Ibrahim, S.F.M. 2000. Thermoregulation in new born lambs and kids under different environmental conditions. Ph.D. Thesis, Fac. Agric., Al-Azhar Univ., Cairo, Egypt.

Kaushish, S. K., S. A. Karim, P. S. Rawat, 2000 Physiological responses and metabolic profile of lambs in growth phase. Indian Journal of Animal Sciences , $70,6,616$.

Khalifa, H.H., 2003. Biometeorology and adaptation of farm animals in a changing climate. Proceeding of the Interaction Between Climate and Animal Production Symposium, Viterbo, Italy, September, 2003, EAAP Technical Series No. 7: 1529.

Khalifa, H.H., A.A. El-Sherbiny, and T.M.M. Abdel-Khalik, 1997. Effect of seasonal variations under Egyptian environmental conditions on adaptability of goats. aadaptability of kids. IAMAS.IAPSO Melbourne,1997 ,1 -9 july. 
Kumar, P. and K. Singh, 1994. Effect of shearing on thermoadaptability in goats of arid and semi-arid zone of India, Indian J. Anim. Sci., 64:290.

Lowe, T.E. , N. G. Gregory, A. D. Fisher, and S. R.Payne, 2002. The effects of temperature elevation and water deprivation on lamb physiology, welfare, and meat quality. Australian Journal of Agricultural Research, 53 , 6, 707-714 .

Piccione, G., A. Costa, E. Giudice, F.Grasso, and G. Caola, 2002. Biological rhythm of body temperature in goats. Bangladesh Veterinarian , 19, 2, 97.

SAS, 1990. Statistical Analysis System Users Guide: Statistics. SAS Inc., Caty, NC.

Shafie, M.M., H.M Murad, T.M. El-Bedawy, and S.M. Salem, 1994. Effect of heat stress on feed intake, rumen fermentation and water turnover in relation to heat tolerance response by sheep. Egyptian J. Anim., Prod., 31: 317.

Shalaby, T.H., and H.D. Johnson, 1993. Heat loss through skin vaporization in goats and cows exposed to cyclic hot environmental conditions. Egyptian American Conf. Physiol. Anim. Prod., November 12-18, El-Fayoum, Egypt, pp. 241.

Shalaby, T.H., O. Salama, and G. Solouma, 1996. Physiological responses to climate changes in Rahmani imported Finn. Rams and their half sub-born to Rahmani recipient in Egypt. J. Anim. Prod., 33: 269.

Srikandakumar, A., E.H. Jonson, and O. Mahgoub, 2003.Effect of heat stress on respiratory rat, rectal temperature and blood chemistry in Omani and Australian Merino sheep .Small Ruminant Research 49,193.

Starling, J. M. C., R. G. Silva, M. Cerón-Muñoz, G. S. S. C. Barbosa and M. J. R. P. Costa, 2002. Analysis of some physiological variables for the evaluation of the degree of adaptation in sheep submitted to heat stress. Revista Brasileira de Zootecnia ,31, 5 , 2070.

Swenson, M.J. and W.O. Reece, 1993. Duke's Physiology of Domestic Animals. Cornell Univ. Press, Ithaca, USA.

Symington, R.B., 1960. Studies on the adaptability of three breeds of sheep to a tropical environment modified by altitude 1-The annual fluctuation in body temperature and body temperature increase between 6.30 a.m. and $12.30 \mathrm{pm}$. J. Agric. Sci., 55: 287.

Terill, C.E., 1968. Adaptation of sheep and goats. Chapter 18: In: Adaptation of Domestic Animals E.S.E. Hafez, (ed.) Lea and Febiger, Philadelphia, USA, pp. 251.

Yousef, M.K. and Dill 1969. Energy expenditure in desert walks: Man and Burro, Equus asinw. J. Appl. Physiol., 27: 681. 


\section{ميكانيكية التظظيم الحرارى فى الجداء و الحملان حليثة الميلاد}

طارق محمد محمد عبد الخالث' و هشام حسين خليفة'

1 - معهل بحوث الانتاج الحيوانس، الدقى، الجيزة، مصر، r - قسم الاتتاج الحيوانى، كلية النزاعة، جامعة

الازهر، مدينة نصر، الثقاهة

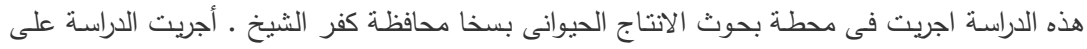

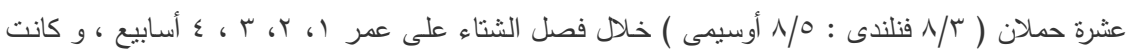

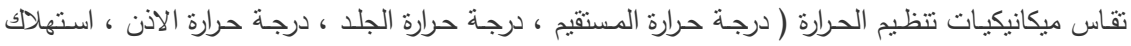

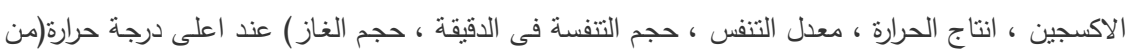

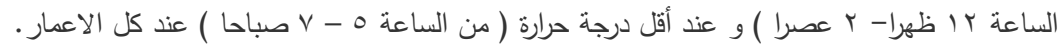

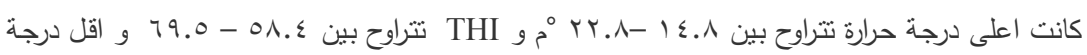

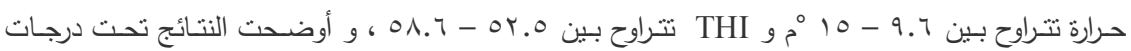

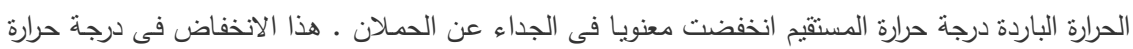

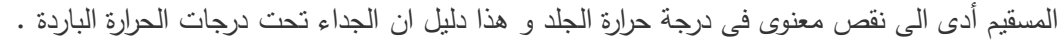

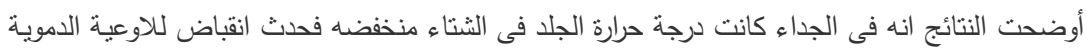

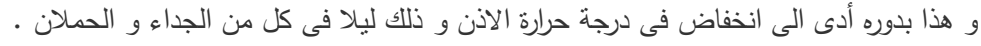

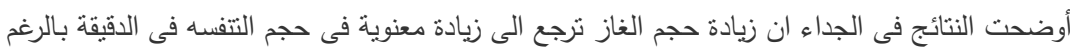

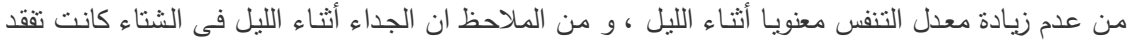

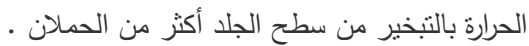

الانتاج الحرارى فى الجداء كان منذفض معنويا عن الحملان و ذلك عند اعلى و اقل درجة حرارة بالرغم

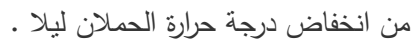

نستتنج من ذلك ان زيادة معدل النفوق فى الجداء عن الحملان يرجع الى نقص فى معدل التمثيل الغذائى و ارتفاع فى الفقد الحرارى ، لذا فان الجداء لا تتحمل انخفاض درجة الحرارة اثناء الليل فى الثتاء. 